Asian Journal of Managerial Science

ISSN: 2249-6300 Vol.8 No.1, 2019, pp. 6-10

(C)The Research Publication, www.trp.org.in

\title{
Creating Wealth for Shareholders: Evaluating the Performance of Merging Companies
}

\author{
V. Shanthaamani ${ }^{1}$ and V. B. Usha ${ }^{2}$ \\ ${ }^{1}$ Professor, Department of Management Studies, Vels University, Chennai, Tamil Nadu, India \\ ${ }^{2}$ Assistant Professor, Department of Economics, LRG Government Arts College for Women, Tamil Nadu, India \\ E-Mail: apshan6@gmail.com, balan.usha5@gmail.com
}

\begin{abstract}
Mergers and Acquisitions as business strategies are widely used to increase the wealth of shareholders and the corporate performance. Shareholders wealth may be influenced by many factors such as the corporate performance, deal type, geographic location of the company and so on. The study is conducted with three main objectives of assessing the impact of merger announcements on merging companies' share prices, analyse the nature of shareholders' returns of the merging companies and assess the determinants of shareholders returns. NSE listed companies which have made merger announcements during the period of $1^{\text {st }}$ January 2012 to $31^{\text {st }}$ December 2017 shall constitute the sample population for the research, while $\mathbf{4 0}$ merger announcements of computer software industry have been taken as sample size. Mean adjusted model has been used for calculating the abnormal returns while the statistical tools of paired samples t-test, ANOVA and multiple regressions have been used for analyzing data. Results of the research reveal that merger announcements exert significant impact on share prices. Further, shareholders wealth has witnessed an increase after the merger announcements. Finally, shareholders wealth has not been affected by the company's performance.

Keywords: Computer Software Industry, Mergers, Mean Adjusted Abnormal Returns
\end{abstract}

\section{INTRODUCTION}

India is witnessing numerous merger deals in the recent past. In India, almost 768 companies have made merger announcements during $1^{\text {st }}$ January 2012 to $31^{\text {st }}$ December 2017, which includes 395 listed companies of NSE. Companies belonging to different industries such as Abrasives, Aluminium products, Animation content provider, Auto finance services, banking services have been listed in NSE. Merger deals have occurred in 395 companies, spread over almost 106 industries during $1^{\text {st }}$ January 2012 to $31^{\text {st }}$ December 2017.

The main objective of this paper is to analyse the shareholder performance and the impact of mergers of computer software industry. The rest of this paper is organized as follows: Section 2 considers the previous theoretical literature that has examined the relationship between firm size, mergers and acquisitions. Section 3 surveys the existing empirical evidence of the merger impact and examines a number of methodological issues relating to measuring the impact of acquisitions. The results are described in Section 4. A brief conclusion follows.

\section{REVIEW OF LITERATURE}

Jayaraman, N., Khorana, A. and Nelling, E., (2002) have analysed the determinants and Shareholder Wealth of mergers. This study has concentrated specially on Mutual Fund Mergers. Delaney, T. and Wamuziri, S.C., (2004) have studied the $\mathrm{M} \& \mathrm{~A}$ impact on shareholders wealth. This study has considered the UK construction industry and found that the related construction mergers have created value to the target firms shareholders.

Anand, M. and Singh, J. (2008) have studied the Impact of Merger Announcements on Shareholders' Wealth. This study dealt with the Indian Private Sector Banks. This study uses event study methodology. Five mergers deals have been taken as sample. This study stated that both the bidder and target bank has the positive impact after the merger announcements. Kumar, R., (2009) studied the post merger corporate performance of the acquiring firms involves in mergers between 1999 and 2002 in India.

Bednarczyk, T.P., Schiereck, D. and Walter, H.N., (2010) have studied the cross-border acquisitions and shareholder wealth of the energy and industry. This study has considered bidder announcements between 1995 and 2005. Shukla, A. and Gekara, M.G., (2010) have studied the multinational M\&A effects on shareholders wealth and corporate performance. This study has found that the acquiring company is earning returns in pre-announcement periods.

Liargovas, P. and Repousis, S., (2011) have studied the M \& A impact on the performance of Banking sectors in Greek. This study has adopted event study methodology approach. This study has considered 1996-2009 merger announcements. This study finds that the operating performance has not improved after M\&A.

Mann, B. and Kohli, R. (2011) have studied the target shareholders wealth creation. This study has considered both the domestic as well as cross border acquisitions. Results revealed that both the domestic as well as cross border acquisitions have created value to the target shareholders. Venkatesan, S. and Govindarajan, K. (2011) have studied the acquisitions of Public Sector Banks and its impact of shareholders wealth. This study has considered 
the banks in India. This study has considered the deals between 1995 and 2006. The abnormal returns were calculated by using market model. This study finds that there is a maximum benefit in the post event period.

Shobhana, V.K and Deepa, N. (2012) have studied the M\&A Impact on the Shareholders Wealth. This study has considered the Acquirer Banks in India. Event study approach is applied. The sample of the study is six bank merger announcement period between 1991 and 2005. This study has found that the shareholders value has been declined after the announcements.

Rahim, N.M. and Ching Pok, W.(2013) have analysed the shareholders wealth. The purpose of this study is to find out short term wealth effects of M\&A and its determinants. This study revealed that there is positive wealth creation for both bidding and target shareholders.

Banerjee et al., (2014) considered all the acquisitions done by Indian acquirers during 1995-2011. They showed that Indian acquirers created shareholder value until 2007; from 2008 to 2011, the returns accrued to Indian acquirers were negative. This study determined the increasing intensity of the market for corporate control as measured by an increased number of participants in M\&A activities to be the reason for the declining acquirer returns in Indian M\&As.

Jagtiani et al., (2016) examined the roles and characteristics of U.S. community banks in the past decade, covering the recent economic boom and downturn. They have analysed risk characteristics of acquired community banks, compare pre- and post-acquisition performance, and investigate how the acquisitions have affected SBL. The results also indicate that mergers involving community bank targets over the past decade have enhanced the overall safety and soundness of the banking system without adversely impacting SBL.

\section{RESEARCH METHODOLOGY}

Event Study methodology has been applied in this research. This study has used the six year period from $1^{\text {st }}$ January 2012 to $31^{\text {st }}$ December 2017 as the study period. Forty merger deals struck by 24 NSE listed companies belonging to computer software industry have been taken as the sample units for the research. The Stock Exchange announcement data is not available, Board of Directors/High Court approval date has been considered as the announcement date.

Shareholders of merging companies are the main focus of this research. Data pertaining to merger transactions have been collected from CMIE database while data pertaining to share prices have been collected from NSE webpage. Statistical tools such as paired samples t-test, ANOVA and multiple regression have been used to analyse data. SPSS 16.0 package has been used for data analysis. Shareholders wealth has been assessed by calculating the abnormal returns. The abnormal returns are calculated by using mean adjusted abnormal returns models with the procedures followed by Brown and Warner (1985).

$$
A_{i t}=R_{i t}-R_{i}
$$

Whereas $R_{\text {it }}$ refers to daily return.

\section{RESULTS AND DISCUSSION}

\section{A. Impact of Mergers on Share Prices - Year Wise Analysis}

Impact of Mergers on share prices can be assessed by comparing the share prices during the pre and post merger period. This study compares the share price movement 20 days before and after the announcement of merger. The average share price of the merging company in a particular year has been considered as the average share price. This study proposes to analyse the impact of merger announcements made during the six year period, on share prices by using paired samples t-test.

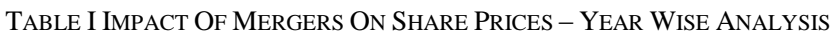

\begin{tabular}{|c|c|c|c|c|c|}
\hline Year & $\begin{array}{c}\text { Before } \\
\text { Mean }\end{array}$ & $\begin{array}{c}\text { After } \\
\text { Mean }\end{array}$ & $\begin{array}{c}\text { Difference } \\
\text { in Mean }\end{array}$ & $\mathbf{t}$ & Sig. \\
\hline 2012 & 189.3825 & 186.14 & -3.25 & 3.442 & 0.003 \\
\hline 2013 & 365.2281 & 457.34 & 92.11 & -15.81 & 0.000 \\
\hline 2014 & 329.2883 & 352.61 & 23.32 & -11.80 & 0.000 \\
\hline 2015 & 367.543 & 355.39 & -12.14 & 3.09 & 0.006 \\
\hline 2016 & 285.4944 & 294.36 & 8.86 & -2.76 & 0.012 \\
\hline 2017 & 321.7589 & 338.65 & 16.89 & -15.39 & 0.000 \\
\hline \multicolumn{6}{|c|}{ Source: Estimated value based on CMIE database }
\end{tabular}

Table I shows the impact of mergers on share prices. Before mean refers to the average share prices during the 20 days before merger announcement, while the after mean refers to the average share price during 20 days after the announcement. It can be observed from the above table that the share prices have displayed a downward trend during 2012 to 2015 as a response to merger announcements, whereas the prices have increased during the rest of the years.

The prices has sharply increased during 2013 and sharply dropped during 2015. The significant value is less than 0.01 which suggest the prevalence of good impact of mergers on share prices, as the share prices have changed significantly after merger announcements.

\section{B. Shareholders Abnormal Returns - Year Wise Analysis}

The abnormal returns can be calculated by using three models namely mean adjusted model, market adjusted model and market model. This study has adopted mean adjusted model for calculating abnormal returns. In the mean adjusted model the past mean returns of the share prices are adjusted with the current returns. The abnormal returns are calculated for 41 days. 20 days before and after announcement of mergers. Day 0 is the announcement day. The abnormal returns are calculated for all the six years. 
TABLE II SHAREHOLDERS ABNORMAL RETURNS - YEAR WISE ANALYSIS

\begin{tabular}{|c|c|c|c|c|c|c|}
\hline \multirow{2}{*}{ Days } & \multicolumn{6}{|c|}{ Abnormal returns } \\
\hline & 2012 & 2013 & 2014 & 2015 & 2016 & 2017 \\
\hline-20 & 0.51 & -1.37 & 0.27 & -0.48 & -0.94 & -0.20 \\
\hline-19 & 0.36 & 1.19 & -0.08 & -0.05 & -1.82 & -1.66 \\
\hline-18 & 0.58 & -3.48 & 0.45 & 0.42 & -0.45 & -0.57 \\
\hline-17 & -1.54 & -0.89 & -0.06 & 0.18 & 0.44 & -0.71 \\
\hline-16 & -0.42 & 3.54 & 0.20 & -0.88 & 0.95 & 0.58 \\
\hline-15 & 0.17 & 2.96 & -1.46 & -0.22 & 1.84 & -0.45 \\
\hline-14 & -0.06 & -4.97 & 1.96 & -1.13 & 0.74 & 0.58 \\
\hline-13 & -1.21 & 1.67 & 2.45 & 1.17 & 2.51 & 0.48 \\
\hline-12 & -0.60 & -3.04 & 3.59 & -0.61 & 0.13 & 0.87 \\
\hline-11 & -0.56 & 3.27 & -1.47 & 0.19 & -0.64 & 0.02 \\
\hline-10 & 0.03 & 3.18 & 0.80 & -0.77 & 1.34 & -0.72 \\
\hline-9 & 0.68 & 0.45 & 2.27 & 0.87 & 1.04 & 0.14 \\
\hline-8 & -0.91 & 3.23 & -1.22 & -0.41 & -0.06 & 1.42 \\
\hline-7 & -0.29 & 1.58 & 1.45 & 2.00 & 0.09 & -0.34 \\
\hline-6 & -0.68 & 0.84 & -1.34 & -0.04 & 2.27 & 0.37 \\
\hline-5 & 2.84 & 4.87 & 2.57 & -0.54 & 0.87 & -0.02 \\
\hline-4 & 0.64 & -1.95 & -2.55 & 1.47 & -2.16 & -1.09 \\
\hline-3 & -0.31 & 1.36 & -1.41 & -0.17 & 0.93 & -0.82 \\
\hline-2 & -0.61 & 1.59 & -0.73 & 0.36 & 1.62 & 0.29 \\
\hline-1 & 0.13 & 0.49 & 2.01 & -0.58 & 0.81 & 2.54 \\
\hline 0 & 0.92 & -1.93 & 3.48 & -0.11 & -0.50 & 0.79 \\
\hline 1 & -0.15 & 4.64 & -1.65 & -1.21 & 0.67 & 3.09 \\
\hline 2 & -0.79 & 11.45 & -2.08 & -0.62 & -0.72 & 0.63 \\
\hline 3 & 0.04 & -2.37 & -2.06 & 0.00 & 0.60 & -0.66 \\
\hline 4 & -2.66 & 2.99 & 1.95 & 0.05 & -0.31 & -0.65 \\
\hline 5 & 2.19 & -0.26 & 1.27 & -7.84 & -0.46 & -0.25 \\
\hline 6 & 2.53 & 4.23 & 0.06 & -0.19 & -0.04 & 0.44 \\
\hline 7 & -1.58 & 6.22 & 0.28 & 1.06 & 0.46 & 0.38 \\
\hline 8 & -0.47 & 2.37 & -0.01 & -1.52 & -1.02 & -0.31 \\
\hline 9 & 1.96 & -4.92 & 0.12 & -0.07 & 1.59 & 0.73 \\
\hline 10 & 0.40 & -3.05 & -0.70 & -0.33 & -0.75 & 0.01 \\
\hline 11 & -0.80 & -0.04 & 1.87 & -0.64 & 0.41 & -0.80 \\
\hline 12 & -0.53 & -2.95 & -0.58 & 0.14 & -1.09 & 0.22 \\
\hline 13 & -1.55 & 1.37 & 0.65 & -0.09 & -1.76 & -0.10 \\
\hline 14 & -0.40 & 0.60 & 1.72 & -0.45 & -0.50 & 0.50 \\
\hline 15 & 3.12 & 10.63 & 0.34 & -1.01 & 0.57 & -0.49 \\
\hline 16 & -0.67 & 1.53 & 1.44 & -0.09 & 0.58 & -0.17 \\
\hline 17 & -2.65 & 4.36 & -0.01 & -1.06 & 0.61 & -1.49 \\
\hline 18 & 1.67 & -2.62 & 2.06 & -0.31 & 0.16 & -0.01 \\
\hline 19 & -0.87 & 3.05 & -2.21 & 0.03 & -0.55 & -1.12 \\
\hline 20 & -0.71 & 1.73 & 0.05 & 0.21 & -0.73 & 0.67 \\
\hline
\end{tabular}

Table II shows the year wise abnormal returns of the merging company shareholders. During 2013, 2016 and 2017, there is a positive abnormal return on the first day after the announcement of mergers, while during 2012, 2014 and 2015; there is a negative abnormal return soon after merger announcements. Table II shows that during 2013, there is tremendous increase in the share price after announcement of mergers. It can further be observed that during 2013, the abnormal returns have increased tremendously during the first day after merger announcement. During 2014 and 2015, the shareholders are getting meager positive abnormal returns on the $20^{\text {th }}$ day after merger announcements, while during 2012 and 2015, the shareholders are getting negative abnormal return on the $20^{\text {th }}$ day. It can further be inferred from the table that during 2012 and 2015, mergers have resulted in negative abnormal returns during the long run.

\section{Comparison of Shareholders Abnormal Returns}

Table II shows the year wise results of merging company shareholders abnormal returns. In this section, the six year abnormal returns are compared using ANOVA so as to explore the existence of any difference in abnormal returns during the six year period.

TABLE III COMPARISON OF SHAREHOLDERS ABNORMAL RETURNS

\begin{tabular}{|c|c|c|c|c|}
\hline Years & $\mathbf{1}$ & $\mathbf{2}$ & F & Sig. \\
\hline 2015 & -0.3137 & & & \\
\cline { 1 - 3 } 2012 & -0.0763 & & & \\
\cline { 1 - 3 } 2017 & 0.0527 & & \multirow{3}{*}{0.533} & 0.004 \\
\cline { 1 - 3 } 2016 & 0.1641 & & & \\
\hline 2014 & 0.3329 & & & \\
\hline 2013 & & 1.2573 & & \\
\hline \multicolumn{3}{|c|}{ Source: Estimated value based on CMIE database }
\end{tabular}

Table III shows the results of ANOVA. Since the significant value is less than one percent, it can be said that there is a significant difference in the abnormal returns during the six years. The abnormal returns are varying year to year. It can be observed that the shareholders are not getting benefited during all merger announcements. From the post hoc results it is clear that five years abnormal returns are lying in the other side. There is a meager difference in abnormal returns during 2015, 2012, 2017, 2016 and 2014. In the year 2013, merger announcements have resulted in maximum wealth for shareholders.

\section{Shareholders Cumulative Returns - Year Wise Analysis}

The shareholders cumulative returns are the results of summation of abnormal returns. This study has used four event window periods of $(-20,20),(-15,15),(-5,5)$ and $(-2$, $2)$. The event window analysis is used to find out whether the merger announcements are giving short term or long run returns to the shareholders of merging company. The announcement dates of $(-20,20),(-15,15),(-5,5)$ and $(-2$, 2) refers to long run, medium term and short run respectively. 
TABle IV Shareholders CUMULATIVE RETURNS - YeAR WiSE ANALYSIS

\begin{tabular}{|c|c|c|c|c|c|c|}
\hline \multirow{2}{*}{$\begin{array}{c}\text { Announcement } \\
\text { Date }\end{array}$} & \multicolumn{6}{|c|}{ Cumulative Abnormal Returns } \\
\hline & 2012 & 2013 & 2014 & 2015 & 2016 & 2017 \\
\hline$(-20,20)$ & $\begin{array}{c}- \\
3.27 \\
\end{array}$ & 51.52 & 13.68 & $\begin{array}{c}- \\
13.31 \\
\end{array}$ & 6.74 & 2.11 \\
\hline$(-15,15)$ & 0.47 & 44.49 & 11.58 & $\begin{array}{c}- \\
11.28\end{array}$ & 8.49 & 6.79 \\
\hline$(-5,5)$ & 1.24 & 20.87 & 0.81 & -9.21 & 1.35 & 3.85 \\
\hline$(-2,2)$ & ${ }^{-}-$ & 16.23 & 1.04 & -2.17 & 1.88 & 7.34 \\
\hline
\end{tabular}

\section{E. Overall Impact of Mergers on Share Prices}

To examine the overall impact of mergers on share prices, this study uses paired samples $t$ test. The six years average share prices are taken for this analysis. The average share price is compared between 20 days before and after announcements of mergers.

Table V Overall IMPact Of Mergers On Share Prices

\begin{tabular}{|c|c|c|c|c|}
\hline Before Mean & After Mean & Difference & $\mathbf{t}$ & Sig. \\
\hline 309.724 & 322.288 & 12.56 & -9.164 & 0.000 \\
\cline { 2 - 5 } Source: Estimated value based on CMIE database
\end{tabular}

Table $\mathrm{V}$ shows the overall impact of mergers on share prices. The difference between before mean and after mean is 12.56. The significant value is less than one percent. Hence, it can be said that mergers exert significant impact on share prices. Merger announcements lead to a sharp rise in the share prices.

TABle Vi Shareholders AbNormal Returns - Overall ANALysis

\begin{tabular}{|c|c|c|c|c|c|}
\hline Days & AR & CAR & Days & AR & CAR \\
\hline-20 & -0.28 & -0.28 & 1 & 0.43 & 0.98 \\
\hline-19 & -0.26 & -0.54 & 2 & 0.89 & 1.32 \\
\hline-18 & -0.23 & -0.49 & 3 & -0.65 & 0.24 \\
\hline-17 & -0.28 & -0.51 & 4 & 0.31 & -0.34 \\
\hline-16 & 0.35 & 0.07 & 5 & -2.14 & -1.83 \\
\hline-15 & 0.21 & 0.56 & 6 & 0.95 & -1.19 \\
\hline-14 & -0.45 & -0.24 & 7 & 1.21 & 2.16 \\
\hline-13 & 1.19 & 0.74 & 8 & -0.27 & 0.94 \\
\hline-12 & 0.18 & 1.37 & 9 & -0.20 & -0.47 \\
\hline-11 & 0.12 & 0.3 & 10 & -0.63 & -0.83 \\
\hline-10 & 0.30 & 0.42 & 11 & -0.06 & -0.69 \\
\hline-9 & 0.97 & 1.27 & 12 & -0.54 & -0.6 \\
\hline-8 & 0.24 & 1.21 & 13 & -0.05 & -0.59 \\
\hline-7 & 1.04 & 1.28 & 14 & 0.28 & 0.23 \\
\hline-6 & 0.12 & 1.16 & 15 & 1.56 & 1.84 \\
\hline-5 & 1.29 & 1.41 & 16 & 0.42 & 1.98 \\
\hline-4 & -0.45 & 0.84 & 17 & -0.15 & 0.27 \\
\hline-3 & -0.16 & -0.61 & 18 & 0.09 & -0.06 \\
\hline-2 & 0.38 & 0.22 & 19 & -0.23 & -0.14 \\
\hline-1 & 0.78 & 1.16 & 20 & 0.35 & 0.12 \\
\hline 0 & 0.55 & 1.33 & & & \\
\hline Source: Estimated value based on CMIE \\
\hline
\end{tabular}

\section{F. Shareholders Abnormal Returns - Overall Analysis}

This study tries to find out the overall shareholders abnormal returns. In the overall analysis, the average of share prices of merging companies during the six years is taken for analysis. 0 shall be the merger announcement day. The abnormal returns are calculated with the help of average share prices.

Table VI shows the abnormal returns and cumulative abnormal returns of merging companies during the six years. On the first and second day after the merger, there is a positive abnormal return. During the middle period of $8^{\text {th }}$ to $13^{\text {th }}$ day after the merger announcements, there is a positive abnormal return. There is a high positive cumulative abnormal return in the $20^{\text {th }}$ day. From the table it is inferred that both in the long as well as in the short run there is an increase in the shareholders wealth after the announcement of the mergers. In the middle there is a slight decrease in the shareholders wealth.

\section{G. Shareholders Cumulative Returns - Overall Analysis}

This study tries to find out whether the shareholders are getting long run or short run CAR. The results are shown in table VII.

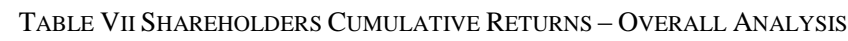

\begin{tabular}{|c|c|}
\hline Announcement Date & CAR \\
\hline$(-20,20)$ & 7.22 \\
\hline$(-15,15)$ & 7.43 \\
\hline$(-5,5)$ & 1.23 \\
\hline$(-2,2)$ & 3.03 \\
\hline
\end{tabular}

Source: Estimated value based on CMIE database

All the event window periods of $(-20,20),(-15,15),(-5,5)$ and $(-2,2)$ are showing the positive CAR. However, the event window $(-5,5)$ has witnessed a low positive CAR while the period of $(-15,15)$ has witnessed a maximum positive CAR. It can be inferred from the above table that the shareholders are getting wealth both in short as well as long run.

\section{CONCLUSION}

This study has revealed that share prices have changed significantly after merger announcements during the six years. Further, it has also been established that mergers exerts significant impact on share prices. Furthermore, the study has revealed that there is a significant change in the abnormal returns during the six years. However, shareholders are not deriving benefits during all merger announcements. CAR analysis has revealed that shareholders have got benefits out of merger announcements. This benefit is at the maximum level in the form of abnormal returns during 2008. Finally the study also revealed that frequent mergers do not influence shareholders wealth. 


\section{REFERENCES}

[1] Anand, M. \& Singh, J. (2008). Impact of Merger Announcements on Shareholders Wealth: Evidence from Indian Private Sector Banks. Vikalpa, 33(1). 35-54.

[2] Banerjee, P., P. Banerjee, S. De, J. Jindra, \& J. Mukhopadhyay. (2014). Acquisition pricing in India during 1995-2011: Have Indian acquirers really beaten the odds? Journal of Banking \& Finance, 38, 14-30.

[3] Bednarczyk, T. P., Schiereck, D. \& Walter, H.N. (2010). Crossborder acquisitions and shareholder wealth: Evidence from the energy and industry in Central and Eastern Europe. Journal for East European Management Studies, 106-127.

[4] Brown S. \& Warner J. (1985). Using daily stock returns: the case of event studies. Journal of Financial Economics, 14, 3-31.

[5] Delaney, T. \& Wamuziri, S. C., (2004). The impact of mergers and acquisitions on shareholder wealth in the UK construction industry. Engineering, Construction and Architectural Management, 11(1), 6573.

[6] Jayaraman, N., Khorana, A. and Nelling, E. (2002). An analysis of the determinants and shareholder wealth effects of Mutual Fund mergers. The Journal of Finance, 1521-1551.

[7] Jagtiani, Julapa \& Kotliar, Ian \& Maingi, Raman Quinn. (2016). Community bank mergers and their impact on small business lending. Journal of Financial Stability. Elsevier, 27(C), 106-121.
[8] Kumar, R. (2009). Post-merger corporate performance: An Indian perspective. Management Research News, 32(2), 145-157.

[9] Liargovas, P. and Repousis, S. (2011). The impact of Mergers and Acquisitions on the performance of the Greek Banking Sector: An Event Study Approach. International Journal of Economics and Finance, 3(2), 89-100.

[10] Mann, B. and Kholi, R. (2011). Target shareholders wealth creation in domestic and cross-border acquisitions in India. International Journal of Commerce and Management. 21(1). 63-81.

[11] Rahim, N. M. \& Ching Pok, W. (2013). Shareholder wealth effects of M \& As: the third wave from Malaysia. International Journal of Managerial Finance, 9(1).

[12] Shobhana, V.K. and Deepa, N. (2012). Impact of Mergers and Acquisitions on the shareholder wealth of the select acquirer banks in India: An Event Study Approach. The IUP Journal of Bank Management, 11(2). 26-31.

[13] Shukla, A. and Gekara, M.G. (2010). Effects of Multinational Mergers and Acquisitions on Shareholders Wealth and Corporate Performance. The IUP Journal of Accounting Research \& Audit Practices, $9(1 \& 2), 44-62$.

[14] Venkatesan, S. and Govindarajan, K. (2011). Acquisition Activities of Public Sector Banks in India and its impact on Shareholders Wealth. International Research Journal of Finance and Economics, 67, 63-71. 